\title{
Konflik Sosial Kegamaan di Pati: dari Motif Teogenetis ke Sosiogenetis atas al Quran dan Hadis
}

\author{
Mohammad Agus Zuhurul Fuqohak \\ Institut Agama Islam Negeri Kudus \\ Fuqohak88@gmail.com
}

\begin{abstract}
This article aims reveal the conflicting motives for understanding the coran and Hadith in Sundoluhur Pati Village, Indonesia. This article uses a phenomenological approach for looking through interviews with five charismatic peoples. This paper uses theory of motives and Bourdieu's theory of habitus, capital and arena. Motive theory is used to reveal the nature and characteristics of the problems, and Bouerdie's theory analyzes the developing problems in order to detect the modals used in arguing. The finding of the article is that the conflict began when the study of the Coran and Hadith with the books of al-Muwafaqat and al-I'tisham by Imam as-Syâthibi could be categorized as a theogenetic motif. The power desired by some figures and the community is a sociogenetic motive because of the community's push for religious leaders to return to old traditions.
\end{abstract}

Keyword: conflict, understanding, sociogenetic, theogenetic 


\begin{abstract}
Abstrak
Artikel ini bertujuan untuk mengungkap motif konflik pemahaman al Quran dan Hadis di Desa Sundoluhur Pati Indonesia. artikel yang menggunakan pendekatan fenomenologi dengan mencari data melalui wawancara pada lima orang yang merupakan kharismatik. Tulisan ini menggunakan toeri motif dan teori Bourdieu tentang habitus, kapital dan arena. Teori motif digunakan untuk mengunggkap corak dan karakteristik masalah, dan teori Bouerdie menganalisis problematika yang berkembang supaya dapat mendeteksi modal yang digunakan dalam berargumentasi. Temuan artikel ialah konflik bermula ketika kajian al Quran dan Hadis dengan kitab al-Muwafaqat dan al-I'tisham karya Imam as-Syâthibi yang dapat dikategorikan sebagai motif teogenetis. Kekuasaan yang diinginkan oleh sebagian tokoh dan masyarakat merupakan motif sosiogenetis karena dorongan masyarakat agar para tokoh agama kembali kepada tradisi lama.
\end{abstract}

Kata Kunci: Konflik, pemahaman, sosiogenetis, teogenetis

\title{
Pendahuluan
}

Desa Sundoluhur terletak di daerah Pati Jawa Tengah bagian selatan, yang dihuni oleh para santri. Namun tidak menutup adanya konflik atas pemahaman al-Quran dan hadis. Munculnya permasalah pemahaman pada awalnya besifat teogenetis, karena hanya dialami oleh para cendekiawan muslim, seperti kai, santri dan sarjana. Adapun permaslah yang berkembang seputar kaidah-kaidah keagamaan, dasar-dasar penetapan hukum dan sejenisnya, yang berdampak pada pembeharuan dalam pemikiran Islam (Muchlas, 1994, p. 8).

Berkembangnya permasalah yang terjadi di kalangan cendekiawan mulai pergeser pada masyarakat kalangan menengan ke bawah. Hal ini bertujuan untuk menguatkan posisi dan kharisma (Sobur, 2003, p. 298). Perubahan motif konflik dari teogenetis menuju ke sosiogenetis menarik untuk dikaji. Pasalnya ada hegemoni, motif, habitus dan arena yang dimainak oleh para pihak yang berkepentingan. Masing-masing tokoh agama yang memiliki otoritas keagamaan memainkan perannya dalam mempengaruhi masyarakat, yang bertujuan untuk menguatkan status sosial-keagamaan. Peran ini dimainkan dengan menawarkan pemaknaan-pemakaan baru dari ajaran otentik agama, seperti al Quran dan hadis Nabi.

Beberapa artikel yang membahas tentang konflik, seperti Hakiki (2017, p. 3) menulis tentang konflik dan integrasi sosial yang membicarakan tentang potensi faktor konflik yang juga mampu menjadi faktor integrasi yang dilakukan di etnis suku Tengger. Artikel tentang konflik identitas sosial masyarakat Kota Temanggung di tahun 2011 (Suparto, 2013, p. 56). Sumartias dan Rahmat (2013, p. 13) menulis tentang memberikan gambaran bahwa 
ketidak-pastian hukum adalah salah satu penyebab dan menjadi potensi terbesar dalam konflik sosial di Desa Manis Lor Kuningan Indonesia. Manajemen konflik pada kepemimpinan kolektif pondok pesantren Lirboyo Kediri yang ditulis oleh Arifin (Arifin, 2018, p. 6). Artikel serupa tentang manajemen konflik adalah upaya penyelesaiannya dalam organisasi (Mohamad Muspawi, 2014, p. 1). Beberapa artikel tersebut berbeda lokus dengan artikel ini dan tidak melihat motif konflik sama sekali.

Artikel ini mengungkap tentang perdebatan para tokoh agama dan cendekiawan muslim yang ada di Desa Sundoluhur terkait dengan ajaran agama dari beberapa kitab yang menjadi kajian. Perdebatan yang terjadi di daerah tersebut pada awal mulanya terbatas pada para kiai, cendekiawan dan beberapa orang yang memiliki pengaruh keagamaan, tetapi belakangan, perdebatan mulai bergeser pada masyarakat setempat sebagai pembela dari masing-masing orang yang diyakini memiliki otoritas keilmuan. Karakter ini yang membedakan dengan kajian-kajian sebelumnya yang bersifat ras, hukum dan manegerial. Meskipun harus diakui bahwa masing-masing kajian memiliki relevansinya sendiri dan saling bertautan.

\section{Metode}

Artikel menggunakan metode kualitatif untuk memahami fenomena sosial keagamaan yang terjadi di masyarakat Desa Sundoluhur. Partisipan dari beberapa unsur, seperti tokoh agama, donatur dan pemuda untuk mendapatkan gambaran utuh dari fenomena konflik keagamaan. Data diambil dengan cara wawancara (Rachmawati, 2007, p. 7), observasi (Herdiansyah, 2015, p. 1) dengan mengamati perkembangan konflik keagamaan, dampak dan tanggapan masyarakat terhadap masalah.

Pendekatan fenomenologis digunakan untuk menganalisis fenomena masyarakat terkait pemahaman dan pengalaman atas ajaran agama dari sumber otentis al Quran dan hadis (Ahimsa-Putra, 2016, p. 4). Peneliti mengambil data secara umum tentang konsep-konsep keagamaan. Kajian obyektif (bracket out) dalam penelitian ini (Suyanto, 2019, p. 3) dengan melihat isu konflik yang berlaku di masyarakat. Teori motif digunakan untuk melihat alasan terjadinya konflik di Desa Sundoluhur. Peneliti mengimplementasikan teori itu untuk menemukan tepat-tidaknya dengan realitas sosial kemasyarakatan (Helaluddin, 2018, p. 2). 


\section{Kajian Teoritis atas Motif pada Konflik Keagamaan}

Motif merupakan dorongan untuk melakukan suatu tujuan tertentu berupa alasan-alasan dan penggerak dalam diri manusia untuk mendapatkan afiliasi, prestasi atau pun kekuasaan. Setiap perilaku manusia memiliki motif yang berbeda-beda dan dapat dianalisa sebagai satu fenomena keagamaan, seperti konflik keagamaan di Desa Sundoluhur Pati. Alex Shobur (2003, p. 298) menyebut bahwa motif dari sisi ilmu sosial terbagi menjadi empat. Yaitu motif tunggal, motif biogenetis, motif teogenetis dan motif sosiogenetis (Muchlas, 1994). Dorongan kuat untuk merespon doktrin agama dan teksnya bisa disebut motif teogenetis (Hilman, 2018, p. 168). Sedang dorongan melakukan sesuatu karena pengaruh keadaan sosial sekitar disebut sosiogenetis (Amalia, 2013, p. 7). Dua motif ini yang nampak dalam konflik pemahaman Alquran dan Hadis di Desa Sundoluhur Pati.

Menurut Pierre Bourdieu dalam Jones (2016, p. 215), motif yang terjadi dan membentuk perilaku dengan terulang-ulang hingga menjadi kekuatan dalam diri seseorang itu disebut sebagai habitus. Habitus adalah pengetahuan yang tidak disadari merujuk berdasarkan rutinitas yang dialami oleh seseorang. Habitus bisa dikembangkan untuk mendapatkan field (arena; ranah). Untuk mendapatkan ranah ini, seseorang harus menguasai modalmodalnya (capital). Kapital itu bermacam-macam. Ada kalanya kapital pengetahuan, kapital ekonomi, kapital relasi dan jaringan atau bahkan ada juga namanya kapital sosial. Berhasil tidaknya seseorang mendapatkan arena dengan kapitalnya tergantung pula dengan strategi (Irianto, 2015, p. 30). Adapun konflik di Desa Sundoluhur Pati belum cukup strategi untuk memainkan modal di panggung sosial, sehingga resistensi masyarakat menjadi kuat dan lemahnya kharisma. Adanya kesalah dalam memilih strategi menyebabkan konflik yang awalnya bersifat teogenetis menjadi sosiogenetis yang melibatkan orang banyak.

\section{Potret Desa Sundoluhur dan Geneologi Konflik Keagamaan}

Desa Sundoluhur adalah pedesaan Indonesia berada di kota Pati Jawa Tengah. Secara geografis Desa Sundoluhur dikelilingi oleh beberapa desa, di bagian Uutara ada desa Karaban, bagian selatan Desa Boloagung, dari Timur ada Desa Brati dan bagian Barat Desa Talun. Luas desa kurang lebih adalah 1.384 $M$ dengan jumlah penduduk yang tidak kurang dari seribu orang. Potensi yang dimiliki oleh Desa Sundoluhur adalah pertanian kacang hijau, jagung, pepadian dan kapuk. Kapuk menjadi ladang pencaharian terbesar masyarakat. Banyak 
masyarakat Desa Sundoluhur yang bekerja sebagai pedagang kasur, bantal dan bahan mebel lainnya. Secara umum, penduduk Desa Sundoluhur bekerja sebagai petani, pedagang, perantau dan pedagang kaki lima. Namun, pekerja kapuk mendominasi dan menjadi sentra karena sebagai produsen kasur. Para pekerja migra dan wiraswata menjadi donatur dalam pembangunan tempat ibadah dan pendidikan, seperti masjid, Taman Pendidikan al Quran (TPQ) dan Madrasah Diniyah (Zuliana, 2011, p. 5). Para donatur tidak hanya terbatas pada struktur pembangunan, tetapi juga operasional pendidikan dan masjid.

Secara profesi, masyarakat Sundoluhur dikenal dengan masyarakat komplek, selain buruh migran dan wiraswata juga dikenal dengan kampung pendidikan karena banyak lulusan perguruan tinggi yang menjadi dokter, pertanian, keagamaan yang lulus dari pesantren maupuan luar negeri. Oleh sebab itu, banyak ustadz atau tokoh agama yang kompeten dalam bidangnya masing-masing, sehingga membangung pendidikan bersama yang berprestasi di tingkat lokal, kecamatan, kabupatan atau bahkan nasional. Lomba-lomba ajang keagamaan, ilmu umum dan pelajaran sekolah sangat didominasi (Darwati, 2012, p. 13). Adapun murid yang belajar tidak hanya dari Desa Sundoluhur, namun juga terdiri dari kota-kota terdekat bahkan kabupaten atau pun provinsi lain.

Awal mula konflik terjadi disebabkan atas perbedaan pemahaman teks keagamaan yang dibawa salah satu toko agama lulusan Timur Tengah. Kajian kitab muwafaqad karya Syatibi tentang ushul fiqh menjadi sumber dalam menguatkan kharisma, dan dapat mempengaruhi kelompok masyarakat untuk mendukung kuasanya. Namun, tokoh tersebut tidak menyadari batas kuasa manusia, sehingga mengira semua harus memenuhi semua kebutuhan yang diharapkan. Pasalnya, otoritas yang dimiliki dianggap dapat mengatur semua kalangan masyarakat. Dampak yang terjadi ialah, masyarakat mulai meninggalkan dan tidak mempercayai tokoh tersebut, sebagaimana diungkapkan partisipan 1.

Ketidak pecayaan masyarakat disebabkan banyak faktor, yaitu hegemoni keluarga, kharisma agama yang berlebihan, otoritas negatif dan ekslusif. Hal ini tidak memberikan ruang diskusi atas kelompok masyarakat lain, seperti donatur dan para ustad. Konflik teologis ini menyisakan pengalaman bagi kelompok masyarkat yang tidak sepaham, sehinggia mendirikan yayasan pendidikan sendiri dan memisahkan dengan yang pertama. Adapun dampak lanjut dari perpecahan tersebut ialah adanya dua shalat Jum'at di masjid berbeda, di mana awalnya berpusat pada masjid tua. 
Lebih lanjut, ada istilah Sundoluhur Timur dan Sundoluhur Barat. Sunde (kependekan dari kata Sundoluhur) Timur dimaksudkan mereka yang telah membuat masjid baru dengan segala piranti pendidikan dan aturan sosial mereka. Sedangkan Sunde Barat diperuntukkan pada penghuni atau jemaah masjid lama dengan segenap piranti pendidikannya pula.

\section{Konflik Keagamaan di Desa Sundoluhur Pati}

Partisipan 1 (beliau adalah tokoh agama setempat dan lulusan al-Azhar Kairo Mesir) menyebutkan bahwa sesungguhnya konflik bermula pada tahun 2009 sekitar bulan Sya'ban 1430 atau bulan Juli 2009. Awal mula bersifat lokal di pengurus yayasan. Tepatnya antar tokoh di desa Sundoluhur. Kemudian konflik mulai membesar dan menyebar pada masyarakat luas hingga di tengah masyarakat. Konflik bisa dikategorikan sebagai konflik jenis intrapribadi. Dahrendorf dalam Beilharz (2003, p. 45) menyebut bahwa konflik intrapribadi terjadi antara dua atau lebih orang dalam satu keluarga atau satu profesi tertentu. Konflik terjadi antara pihak pengelola yayasan. Konflik intrapribadi ini bisa saja terjadi karena bermotif kekuasaan dalam unsur peran keluarga atau pun yayasan. Nampaknya, motif kuasa inilah yang mendominasi dalam konflik tersebut. Terbukti konflik itu belum bisa memberi ujung integrasi (MC Clelland, 1985, p. 35).

Fenomena yang terjadi di tengah masyarakat Sundoluhur bisa dikategorikan sebagai motif atribusi (Samsuar, 2019, p. 1). Motif antribusi melihat fenomena berdasarkan sebab-akibatnya (Iksan, 2015, p. 2). Awal konflik di Desa Sundoluhur karena adanya keinginan dari para tokoh untuk mengubah kebudayaan dan adat istiadat yang kuat di tengah masyarakat. Hal ini diawalai dengan pengajian kitab asy-Syâthibi berjudul "al-Muwafaqat" yang membicarakan tentang Ushul Fiqh. Satu cabang ilmu yang mempelajari tentang dasar-dasar penetapan hukum Islam, pencarian dalil-dalil agama yang bisa dipertimbangkan serta etika seseorang menjadi mujtahid yang akan memberikan fatwa dan pemahamaan keagamaan kepada umatnya. Beberapa ulama menambahkan judul kitab itu dengan "fî Ushul al-Ahkkam" ada yang lain pula menyebutnya "fî Ushul as-Syari'ah", "fî Ushul al Fiqh" (Kahalah, 1993, p. 77).

An-Natbakti (2000, p. 48) mengatakan kitab al-Muwafaqat adalah kitab yang sangat agung dan tidak ada padannya. Thahir bin 'Asyur dalam Timur (2003, p. 76) menyebut bahwa as-Syathibi adalah Bapak Maqasid Syari'ah. Kitab al-Muwafaqat bisa memberikan solusi masalah di era kekinian dengan 
membangkitkan tradisi merenung dan berfikir. Kitab yang mendeskripsikan maslahat-mudharat, memerinci apa saja cara mengetahui relevansi dan korelasi agama dengan kehidupan sosial kemasyarakatan yang ada. Para tokoh di desa Sundoluhur itu sepertinya juga sama kagum dengan kehebatan asSyathibi.

Pengajian yang ada di Desa Sundoluhur atas kitab asy-Syathibi meliputi al-Muwafaqat dan al-I'tishâm. Masing-masing dikajia untuk menemukan pesan yang ada dalam kedua kitab asy Syatibi. Kitab al-Muwafaqat menjelaskan tentang maqasid dan al-I'tisham menjelaskan tentang bid'ah dan problematikanya (Asy-Syathibi, 2008, p. 26). Kajian dua kitab as-Syathibi memunculkan persoalan di Desa Sundoluhur. Diskusi-diskusi keagamaan yang dulunya terlihat sangat langka didengar dan hampir mustahil diucapkan masyarakat awam, setelah adanya kajian masyarakat mulai berani berdebat dan menjadi hal mainstream. Terminologi seperti hadis yang sahih, dha'if, maudhu' (palsu) menjadi bahan pembicaraan sehari-hari.

Kajian yang dilakukan para tokoh agama di tengah masyarakat memberikan pengetahuan dan perilaku yang berkelanjutan. Pengetahuan dan perilaku membentuk kebiasaan yang biasa disebut dengan habitus (Rabinow \& Bourdieu, 2018, p. 3). Diskusi-diskusi keagamaan yang dilakukan oleh para tokoh lalu memberikannya kepada masyarakat awam adalah bentuk habitus yang dibuat secara sistematis oleh para tokoh di Desa Sundoluhur itu sehingga mereka akan mendapatkan kapital (modal) pendidikan yang kuat untuk diarahkan menuju ranah arena (field) yang mereka harapkan. Arena benarbenar nampak ketika klaim dari para tokoh masyarakat yang mengatakan bahwa beberapa tradisi yang sudah berlaku di desa sana banyak unsur bid'ah. Ada tiga isu sosial yang mereka anggap bid'ah dan perlu bahkan sangat-sangat harus untuk ditinggalkan.

Pertama, membaca manaqib dikategorikan bid'ah yang wajib dijauhi, hal ini disebabkan Nabi Saw dan para sahabatitu tidak pernah mengajarkan. Selain itu, teks dan kandungan makna manaqib ini terlalu mengada-ada dan irrasional, seperti cerita Syaikh Abdul Qadir yang tidur dan bangun satu malam sebanyak empat puluh kali demi mandi jinabat dianggap tidak realistis, dan cerita yang dikandung dianggap merupakan keangkuhan dalam berdoa. Kedua, membaca talqin mayit, yaitu orang-orang yang ikut berziarah kubur akan berhenti sejenak mendengarkan tanya jawab yang dibacakan oleh Bapak Modin Desa (tokoh agama di desa) berisi apa saja pertanyaan malaikat MungkarNakir dan jawabannya. Fenomena ini dianggap bid'ah yang harus ditinggalkan. 
Ketiga, ritual baca tahlil untuk si mayit. Tradisi masyarakat Islam yang melantunkan bacaan al Quran dan dzikir bagi orang yang telah meninggal dunia sebagai bentuk hadiah khusus bagi mayit dengan harapan diampuni dosa-dosanya. Praktik keagamaan demikian juga dianggap sebagai praktik yang melanggar ajaran murni agama yaitu al Quran dan hadis Nabi.

Pada tahun 2009-2013 kajian tentang agama yang berhubungan dengan tradisi digalakkan, sehingga banyak praktik keagamaan masyarakat dianggap tidak sesuai dengan ajaran asli Islam, seperti beberapa klaim bidah, kurafat dan taqlid. Puncaknya ketika, ada seorang khatib yang menyampaikan khutbahnya dengan menyebutkan beberap amala yang diaykini sebagia bentuk bidah yang harus ditinggalkan, masyarakat mulai merasa resah dan bahkan meninggalkan khatib ketiak sedang menyampaikan khutbahnya, tepanya pada tahun 2014 (partisipan 2). Adapun konsekuensinya ialah masyarkat mulai menyadari akan pentingnya ajaran agama pada orang yang kompenten dan menyadari sosiokultural masyarakat, sehingga mencari tokoh agama yang menjadi kontra narasi dari kajian kitab as Syatibi.

Teori Bordiue nampak dalam habitus yang ditambahkan dengan kapital itu mampu membentuk arena tertentu maka akan terjadi dialog di tengahtengah sosial masyarakat yang bisa berujung kepada konflik atau bisa saja disebut sebagai kegagalan dari arena yang diciptakan karena kurangnya modal (capital) yang tentu itu bisa terjadi disebabkan kurang kuatnya habitus masyarakat. Habitus yang diciptakan dengan struktur yang kurang begitu kuat justru akan menimbulkan perlawanan atau yang sering disebut sebagai konflik (Shammas \& Sandberg, 2016, p. 195). Mediasi sudah berusaha dilakukan dengan baik. Tawaran dari masyarakat para tokoh agama harus menghentikan kajian kitab as-Syathibi dan kembali kepada kebersamaan tanpa harus mencaci dan menyebut bid'ah amalan-amalan nenek moyang. Ini adalah salah satu bentuk manajemen konflik yang diharapkan masyarakat (Mohamad Muspawi, 2014).

\section{Analisis Motif Teogenetis dan Sosiogenetis dari Konflik karena Pemahaman al Quran dan Sunnah}

Ada tiga masalah penting yang pernah peneliti diskusikan dengan tokoh agama terkait sebagai partisipan 2 (beliau adalah lulusan Pesantren) yang menjadi prinsip dasar pemahaman keagamaan mereka terhadap al Quran dan sunnah Nabi saw. Pertama, masalah taqlid, bid'ah dan tawassul. Taqlid berarti mengikuti ucapan dan tindakan orang lain tanpa mengetahui lebih mendalam 
apa saja dalil-dalil yang digunakannya. Sedangkan bid'ah adalah hal baru yang tidak diajarkan Baginda Nabi saw dan para sahabat. Sementara tawassul itu meminta Allah swt lewat sarana makhlukNya, baik berupa amal kesalehan atau pun kepribadian seseoran yang agung.

Tentang masalah taqlid, partisipan 2 menyebut bahwa setiap orang itu harus belajar secara maksimal tentang masalah agama. Partisipan 2 cenderung setuju dengan pernyataan ulama yang mengharamkan taqlid di dalam masalah fikih. Alasannya, taqlid hanya membuat orang-orang bermalasan untuk belajar keagamaan, sehingga dengan melarnag taqlid, diharapkan masyarakat giat dalam belajar dan memahami ilmu-ilmu agama. Nampaknya, motif para tokoh bersikukuh memahami al Quran dan hadis dengan pengetahuan ini adalah manivestasi dari motif teogenetis (Saprudin et al., 2016, p. 1).

Menurut partisipan 2, Allah swt juga mengecam taqlid semisal dalam QS. Al-Maidah: 104, QS. Al-Baqarah: 170 dan QS. Luqman: 21 yang menjelakan bahwa orang-orang kafir yang diajak Nabi saw untuk masuk Islam itu menjawabnya tidak mau karena menghidupkan tradisi nenek moyang mereka. QS. Al-Isra': 36. Allah swt melarang untuk membahas atau melakukan perbuatan tanpa didasari oleh ilmu yang jelas sumbernya, karena pendengaran, penglihatan dan hati fikiran itu akan dipertanyakan kelak oleh Allah swt sebagai bentuk pertanggung-jawaban. Ayat ini mengindikasikan larangan ikut-ikutan orang lain dalam masalah agama. Sebaliknya, keilmuan dengan belajar yang kuat itu sangat diperlukan sekali (Rumi, 1983, pp. 359360). Praktik bid'ah menjadi perbincangan hangat di tengah masyarakat. Menurut partisipan 2 dengan mengutip beberap hadis seperti riwayat Imam alBukhari dari Aisyah ra dan Imam Ahmad bin Hambal dari Irbadh bin Sariyah:

Bid'ah itu sudah lengkap definisinya dalam hadis bahwa siapa pun yang membuat hal baru dalam perkara kami yang tidak dari ajaran agama maka dia ditolak (Muhamad bin Ismail al-Bukhari, 2011, p. 184). segala sesuatu yang baru itu adalah bid'ah dan segala bid'ah itu sesat (Hambal, 2010, p. 373). Menurut partisipan 2 Tawassul dan manâqib contoh bid'ah karena membolehkan dengan menggunakan hadis tentang Adam as yang meminta pertolongan Allah swt agar dimaafkan segala dosa dan kesalahannya melalui Nabi saw itu disebutnya hadis yang sangat lemah sekali, karena Imam alHakim dalam kitab al-Mustadraknya dan beliau termasuk orang-orang yang mempermudah (mutasahil). Begitu juga dengan hadis-hadis lain yang berkaitan dengan tawassul memiliki kualits transmisi palsu dan sangat lemah. Beberapa sumber tersebut tidak dapat dijadikan sebagai argumentasi dalam 
amaliah keseharian masyarakat. Usaha untuk memurnikan syariat dari hal-hal baru yang mengganggu keyakinan beragama adalah esensi dari orang-orang yang menolak bid'ah. Motif semacam ini tentunya lebih dominasi faktor subyektivitas beragama, karena kuatnya pemahaman yang didasarkan pada dirinya sendiri, tetapi pembahasan tentang bid'ah masih menjadi perdebatan ulama.

Permaslahannya ialah pemilihan pendapat tertentu untuk justifikasi fenomena tertentu adalah bentuk subyektif. Sama halnya dengan tafsir-tafsir keagamaan juga tidak bisa terlepas dari subyektivitas (Mujahidin, 2012, p. 341). Motif teogenetis juga sangat nampak dalam pendapat para tokoh agama. Mereka merespon praktik kegamaan dan merealisasikan norma-norma agama Islam di kehidupan masyarakat (Pramiyanti et al., 2017, p. 97). Norma yang dimaksudkan adalah aturan-aturan agama Islam untuk meninggalkan bid'ah dianggap haram atau dilarang mutlak dan wajib untuk dijauhi. Motif teogenetis juga bisa diuraikan dalam tujuan para tokoh untuk mengentaskan masyarakat dari kesalahan atau pun dosa. Hal semacam ini biasa dikenal mereka dengan istilah hijrah (Putra, 2019, p. 226). Secara bahasa, hijrah diartikan sebagai meninggalkan sesuatu. Terminologi hijrah itu dipakai oleh generasi awal Islam untuk meninggalkan satu tempat demi menuju ke tempat yang lain. Semisal Baginda Nabi saw hijrah meninggalkan kota Mekah menuju kota Madinah. Itu disebut sebagai hijrah. Makna hijrah mengalami pergeseran dan dikuatkan dengan sebuah riwayat hadis yang mengatakan bahwa tidak ada lagi hijrah di dalam Islam (Al-Bukhari, 1992, p. 4312).

Para ulama menyebutkan bahwa maksud hadis tersebut adalah hijrah dalam arti meninggalkan tempat menuju ke tempat lain itu tidak ada lagi, sebab pasca hijrah Nabi saw itu kesulitan membedakan antara negara Islam dan negara non Islam. Dengan demikian, semua bumi dan negara itu dianggap sama oleh Allah swt. (An-Nawawi, 2010, p. 11). Hijrah diartikan sebagai usaha seorang muslim untuk meninggalkan maksiat dan dosa menuju taat dan ibadah kepada Allah swt (Al-Bukhari, 1992). Semisal orang yang gemar mabuk minuman keras, berzina atau melakukan perjudian maka hijrahnya tidak harus meninggalkan desanya tersebut. Namun, hijrahnya adalah dengan meninggalkan dosa-dosa di masa lalunya dan dia memperbaiki kesalahankesalahan tersebut serta mengganti kebaikan di masa depannya.Hijrah seperti makna inilah yang diinginkan oleh para tokoh agama dalam rangka mengajak dan mengarahkan masyarakat untuk meninggalkan dosa bid'ah tersebut. Namun, masalah konflik menjadi terwujud dikarenakan habitus dan kapital 
yang kurang kuat dalam istilah Bourdieu. Sehingga dengan begitu, arena yang semestinya terjadi dengan baik pun tidak terwujud. Sebaliknya, konflik menjadi tidak terelakkan pada fenomena itu.

Motif teogenetis lain dari kasus konflik tersebut adalah dorongan untuk mempelajari agama (Nawawi, 2007, p. 2). Jadi, para tokoh di sana menghendaki agar para masyarakat berusaha untuk belajar kembali ilmu-ilmu agama Islam. Hal ini nampak dalam prinsip larangan taqlid dalam mengamalkan keislaman. Sebab, taqlid itu menyebabkan orang-orang bisa malas belajar dan tidak memiliki rasa keingin-tahuan yang sangat besar di dalam memahami nilainilai agama Islam (Rumi, 1983). Sesungguhnya motif ini sangat baik dan terpuji. Karena mengentaskan masyarakat dari kebodohan adalah usaha yang sangat bagus. Orang-orang akan semakin akrab dengan al Quran, hadis, perkataan-perkataan para ulama dan tentunya sikap serta perilaku mereka akan mencerminkan isi kajian yang mereka diskusikan setiap harinya. Ini bisa saja disebut sebagai motif berprestasi, yaitu para tokoh berusaha bersaing untuk mengarahkan masyarakat kepada kebaikan (Ninawati, 2002, p. 3). Motif saja sesungguhnya belum cukup. Isi kajian juga harus diperhatikan. Meminjam bahasa Bourdieu adalah kapitalnya. Modal untuk menuju arena harus dipertimbangkan dengan matang (Ginting, 2019, p. 47).

Menurut Krisdinanto (2016, p. 189) modal menduduki peringkat kedua dan sangat penting setelah habitus itu sendiri. Kapital yang dia tidak hanya materi saja, namun apa saja yang bisa dijadikan sebagai sarana untuk menuju tujuan tertentu itu juga bisa disebut sebagi kapital. Dalam masalah ini, para tokoh memang sudah membentuk habitus dengan baik. Namun modal untuk menuju perubahan tradisi itu belum cukup. Cara penyampaian, membaca lapangannya, melihat reaksi yang timbul di tengah-tengah masyarakat, tanggapan tokoh lain atau pun juga melihat ada-tidaknya potensi konflik yang akan timbul setelahnya. Ini sangat penting sebagai kapital mereka untuk menuju arena yang mereka harapkan. Secara alamiah konflik yang terjadi di tengah masyaraka lebih bersifat keagamaan. Namun ada motif lain yang melatar-belakangi itu semua, karena tokoh-tokoh yang bersikukuh untuk menyebut istilah bid'ah dengan segenap konsekuensinya itu sekarang mulai lentur dan menerima kembali paham masyarakat secara umum dengan cara moderat dan menghargai satu sama lain. Sementara itu, motif teogenetis yang mulai menghilang itu semestinya bisa meredakan konflik dan berakhir integrasi (Retnowati, 2014, p. 2). 
Awal mula konflik itu terjadi karena ada masalah finansial dalam yayasan. Ini lebih kepada faktor internal dalam diri mereka. Salah satu tokoh yang sangat berpengaruh di yayasan tersebut meminjam uang dengan nominal yang tidak sedikit dan berjanji akan mengembalikannya. Namun, sampai batas waktu yang ditentukan janji yang telah disebutkan itu tidak kunjung tiba dan si peminjam tidak membayar sesuai temponya. Akhirnya atas kesepakatan bersama tokoh-tokoh lainnya, pimpinan yayasan memiliki inisiatif untuk mengingatkan kepada peminjam tadi akan kewajiban yang harus segera ditunaikan, sebagai konsekuensi ialah pimpinan bisa mengeluarkan secara paksa dari yayasan.

Ada faktor sosiogenetis, yaitu motif yang dipelajari oleh seseorang dan motif memang berasal dari pengaruh lingkungan dan kebudayaan setempat (Pramiyanti et al., 2017). Motif konflik berdasarkan informasi adalah adanya hubungan interaksi sosial antar tokoh tersebut yang kemudian menimbulkan kesalah-pahaman atau pun tidak sesuai dengan kesepakatan bersama hingga menimbulkan konflik itu sendiri. Begitu juga motif afiliasi kekuasaan juga sangat dominan, yaitu keinginan dan dorongan dalam bersosialkemasyarakatan untuk mendapatkan ruang, panggung dan bisa mengatur orang lain dalam berorganisasi. Ini juga pengembangan dari motif kognitif seseorang yang ingin memperlihatkan eksistensi dirinya. Sehingga dia pun memiliki dampak positif di tengah-tengah masyarakat. Masing-masing tokoh berebut untuk mendapat hak kuasa mengatur yayasan.

Analisis sosiologis digunakan melihat fenomena habitus pengetahuan yang diberikan oleh para tokoh di Desa Sundoluhur ini bisa berubah menjadi modal pengetahuan yang akhirnya bisa menjadi alat kuasa di tengah-tengah masyarakat. Oleh karenanya, motif kuasa juga mendominasi para tokoh dalam melakukan kebijakan atau pendapat-pendapat mereka (Fauzi et al., 2019, p. 13), sosiogenetinya nampak dari motif ingin mendapatkan kekuasaan. Motif sosiogenetis juga nampak dari respon masyarakat setempat. Dorongan masyarakat untuk meminta para tokoh yang bersikukuh dengan prinsip teogenetisnya itu juga memberi peran timbulnya konflik yang berkepanjangan (Istiqomah \& others, 2017, p. 5).

Prinsip masyarakat agar mengembalikan desa mereka sama seperti dahulu tanpa ada ajaran-ajaran dan pemikiran nyeleneh yang baru itu juga bisa dikategorikan sebagai motif sosiogenetis pula. Partisipan 3 dan 4 (keduanya adalah perwakilan dari para donatur yang kaya raya) mengatakan bahwa mereka baru sadar dan tahu akan keuntungan para tokoh dalam mengelola 
yayasan. Misalnya adalah bantuan dari pemerintah pusat atau pun daerah, penghargaan berupa piala atau atau pun piagam-piagam yang didapatkan dari ajang lomba dan kompetisi, nilai kekuasaan di mata masyarakat dan beberapa keuntungan material atau pun immaterial.

\section{Simpulan}

Awal timbulnya konflik di Desa Sundoluhur terlihat karena motif teogenetis. Keinginan para tokoh untuk mengajak masyarakat dalam mempelajari ilmu-ilmu agama Islam, mengubah adat kebiasaan mereka yang dianggap bid'ah menuju ke perilaku yang sesuai dengan tuntunan Alquran dan Sunnah. Hijrah dengan meninggalkan maksiat menuju taat kepada Sang Pencipta juga menjadi motif teogenitis mereka. Habitus dan kapital yang mereka lakukan belum tepat sehingga arena yang mereka inginkan pun belum didapat.

Ada motif lain di balik fenomena tersbut yaitu motif sosiogenetis berupa motif afiliasi kekuasaan yang sangat mendominasi. Ada tokoh lain yang ingin mendapatkan kekuasaan dan sengaja membuat isu agar terjadi konflik dan dia mendapatkan arena sesuai dengan yang dia harapkan. Motif ini sangat mendominasi sehingga menjadikan pergeseran motif dari teogenetis menuju sosiogenetis. Motif sosial ini perlu dianalisis dengan sosiologis. Hasilnya adalah habitus yang dimiliki para tokoh dan berkembang menjadi modal itu kurang diimbangi dengan strategis yang baik sehingga para tokoh kurang mendapatkan arena yang baik pula.

Kajian sosial keagamaan yang ada relevansinya dengan pemahaman alQuran dan hadis seperti ini perlu banyak dilakukan. Sebab, isu sosial yang seringkali dikaitkan dengan isu keagamaan itu banyak mendatangkan masalah-masalah besar manakala tidak ditangani dengan serius. Isu agama akan mudah menyulut emosi penganutnya sehingga wawasan ilmu sosial dan relevansinya dengan isu-isu agama apapun. Terbukti konflik di Desa Sundoluhur itu mulai menghilang manakala para masyarakat faham akan adanya isu sosial di dalamnya. 


\section{Referensi}

Ahimsa-Putra, H. S. (2016). Fenomenologi Agama: Pendekatan Fenomenologi Untuk Memahami Agama. Walisongo: Jurnal Penelitian Sosial Keagamaan.

https://doi.org/10.21580/ws.2012.20.2.200

Al-Bukhari, M. ibn B. (1992). Al-Jami' al-Shahih. Dar al-Hadits.

Amalia, I. N. (2013). Motif Sosial Masyarakat Desa Baros Kecamatan Ketanggungan Kabupaten Brebes Dalam Merespon Pengajian Akbar. Yogyakarta: Skripsi Fakultas Ushuluddin, UIN SUKA.

An-Natbakti, A. B. bin A. bin A. bin U. bin M. (2000). Nailu al-Ibtihaj Bi Tathriz adDibaj. Dar al-Katib.

An-Nawawi, Y. bin S. (2010). Ad-Dibaj Syarh Sahih Muslim. Dar al-Kutub al-Ilmiyah.

Arifin, Z. (2018). Manajemen Konflik Pada Kepemimpinan Kolektif BPK-P2L Pondok Pesantren Lirboyo Kediri. Jurnal Pemikiran Keislaman.

https://doi.org/10.33367/tribakti.v29i1.616

Asy-Syathibi, I. bin M. bin M. (2008). Al-I'tisham. Maktabah at-Tauhid.

Beilharz, P. (2003). Teori-Teori Sosial: Observasi Kritis Terhadap Para Filsof Terkemuka. Pustaka Belajar.

Darwati, D. (2012). Penggunaan Media Realita Untuk Meningkatkan Kualitas Pembelajaran Matematika Di Kelas IV SD Negeri Sundoluhur 02 Kecamatan Kayen Kabupaten Pati Tahun Pelajaran 2012/2013. Universitas Muhammadiyah Surakarta.

Fauzi, A., Kholifah, S., \& Fitrianita, T. (2019). Pengetahuan sebagai alat kuasa penundukan santri. Oetoesan-Hindia: Telaah Pemikiran Kebangsaan, 1(1), 13-20.

Ginting, H. S. P. H. (2019). Novel Sang Pemimpi karya Andrea Hirata: Analisis Habitus dan Modal dalam Arena Pendidikan Menurut Perspektif Pierre Bourdieu. Sintesis, 13(1), 47-56.

Hakiki, K. M. (2017). Konflik dan Integrasi Sosial (Telaah Buku A. Malik MTT berjudul "Pura dan Masjid; Konflik dan Integrasi. Al-Adyan.

https://doi.org/10.24042/ADYAN.V9I2.1414

Hambal, A. bin. (2010). Al-Musnad. Darul Kutub.

Helaluddin. (2018). Mengenal lebih dekat dengan pendekatan fenomenologi: sebuah penelitian kualitatif. Uin Maulana Malik Ibrahim Malang.

Herdiansyah, H. (2015). Wawancara, Observasi, dan Focus Groups sebagai Instrument Penggalian Data Kualitatif. In Metodologi Penelitian.

Hilman, Y. A. (2018). Motif Wanita Rawan Sosial dan Ekonomi Dalam Komunitas Ikatan Janda Muslimah Ponorogo (IJMP). Simulacra, 1(2), 163-172.

Iksan, M. (2015). Atribusi Kegagalan Berprestasi Siswa SMP dan SMA. Jurnal Psikologi Tabularasa.

Irianto, A. M. (2015). Interaksionalisme Simbolik - Pendekatan Antropologis Merespon 
Fenomena Keseharian. Pustaka Mandiri.

Istiqomah, I., \& others. (2017). Motif Menikah Muda Pada Remaja Putri Di Desa Tetel Kecamatan Pengadegan Kabupaten Purbalingga. IAIN.

Jones, Pip, Bradbury, L. (2016). Pengantar Teori-Teori Sosial (P. O. Indonesia (ed.)). Pustaka Obor Indonesia.

Kahalah, U. R. (1993). Mu'jam al-Muallifin. Muassasah al-Risalah.

Krisdinanto, N. (2016). Pierre Bourdieu, Sang Juru Damai. KANAL: Jurnal Ilmu Komunikasi, 2(2), 189-206.

Mc Clelland, D. C. (1985). Human Motivation. Scott Foresman.

Mohamad Muspawi. (2014). Manajemen Konflik ( Upaya Penyelesaian Konflik Dalam Organisasi ). Journal of Chemical Information and Modeling.

Muchlas, M. (1994). Perilaku Organisasi. PT. Karipta.

Muhamad bin Ismail al-Bukhari. (2011). al-Jami' as-Sahih al-Musnad al-Muttasil Ila Rasulillah. Darul Kutub.

Mujahidin, A. (2012). Subyektivitas Dan Obyektivitas Dalam Studi Al-quran (Menimbang Pemikiran Paul Ricoeur Dan Muhammad Syahrur). Kalam, 6(2), 341-362.

Nawawi, N. (2007). Motivasi Terhadap Tingkah Laku Dalam Proses Dakwah. KOMUNIKA: Jurnal Dakwah Dan Komunikasi, 1(2).

Ninawati. (2002). Motivasi Berprestasi. In Jurnal Ilmiah Psikologi Terapan.

Pramiyanti, A., Putri, I. P., \& Nureni, R. (2017). Motif remaja dalam menggunakan media baru (studi pada Remaja di Daerah Sub-Urban Kota Bandung). Komuniti: Jurnal Komunikasi Dan Teknologi Informasi, 6(2), 95-103.

Putra, A. (2019). Motivasi Marbut Masjid Di Kelurahan Anduring Kecamatan Kuranji Kota Padang (Studi Terhadap Mahasiswa UIN Imam Bonjol Padang). NUANSA: Jurnal Penelitian Ilmu Sosial Dan Keagamaan Islam, 16(2), 223-235.

Rabinow, P., \& Bourdieu, P. (2018). Structures, Habitus, Practices. In Rethinking the Subject. https://doi.org/10.4324/9780429497643-2

Rachmawati, I. N. (2007). Pengumpulan Data Dalam Penelitian Kualitatif: Wawancara. Jurnal Keperawatan Indonesia. https://doi.org/10.7454/jki.v11i1.184

Retnowati, R. (2014). Agama, Konflik, dan Integrasi Sosial (Integrasi Sosial Pasca Konflik, Situbondo). Analisa. https://doi.org/10.18784/analisa.v21io2.14

Rumi, F. bin A. bin S. al. (1983). Manhaj al-Madrasah al-'Aqliyyah al-Haditsah Fi atTafsir. Idarah al-Buhuts al-Ilmiyyah.

Samsuar. (2019). ATRIBUSI. Jurnal Network Media. https://doi.org/.1037//00332909.I26.1.78

Saprudin, M., Amali, M., \& Narulita, S. (2016). Motivasi Pemakaian Jilbab Mahasiswi Islam Universitas Negeri Jakarta. Jurnal Online Studi Al-Qur'an.

https://doi.org/10.21009/jsq.012.2.04 
Shammas, V. L., \& Sandberg, S. (2016). Habitus, capital, and conflict: Bringing Bourdieusian field theory to criminology. Criminology \& Criminal Justice, 16(2), 195-213. https://doi.org/10.1177/1748895815603774

Sobur, A. (2003). Psikologi Umum. Pustaka Setia.

Sumartias, S., \& Rahmat, A. (2013). Faktor-faktor yang Mempengaruhi konflik sosial. Jurnal Penelitian Komunikasi, 16(1), 13-20.

Suparto, D. (2013). Konflik Identitas Sosial Masyarakat Temanggung (Kajian Kekerasan Sosial di Temanggung Tahun 2011). Konflik Identitas Sosial Masyarakat Temanggung (Kajian Kekerasan Sosial Di Temanggung Tahun 2011), 3(1), 56-72. https://doi.org/10.14710/politika.4.2.2013.47-61

Suyanto, S. (2019). Fenomenologi Sebagai Metode dalam Penelitian Pertunjukan Teater Musikal. Lakon Jurnal Pengkajian \& Penciptaan Wayang, 16(1).

Timur, A. (2003). A'lamu al-Fikri al-Islami Fi al-Ashri al-Hadits. Dar al-Afaq alArabiyyah.

Zuliana, Z. (2011). Pengaruh profesionalisme guru mata pelajaran aqidah akhlaq terhadap motivasi belajar siswa di MI Nihayaturraghibin Sundoluhur Kayen Pati tahun pelajaran 2010/2011. IAIN Walisongo. 